\title{
Interactive effects of water salinity stress and chitosan foliar-spray application on vegetative and flowering growth aspects and chemical constituents of pot marigold (Calendula officinalis L.) plant.
}

\author{
Abdel-Mola, M.A.M ${ }^{1}$ and Ayyat, A.M. ${ }^{2}$ \\ ${ }^{1}$ Department of Horticulture (Ornamental Plants), Faculty of Agriculture, Beni-Suef University, Egypt. \\ ${ }^{2}$ Department of Medicinal and Aromatic plants, Faculty of Agriculture, Beni-Suef University, Egypt. \\ *Corresponding author: E mail: mostafa.abdo@agr.bsu.edu.eg
}

Received on: 25/10/2020

Accepted on: 1/12/2020

\begin{abstract}
A pot experiment was conducted during the two successive seasons of 2018/2019 and 2019/2020 at west of Somosta, Beni-Suef governorate, Egypt, to explore the effect of both saline water and foliar application of chitosan treatments on growth parameters for vegetative and flowering and on some chemical constituents of Calendula officinalis L.

In contrast to control plants which were irrigated with tap water, the plants were irrigated with saline water containing $\mathrm{NaCl}$ at concentrations of 1000, 2000, 3000, 4000 and $5000 \mathrm{ppm}$. They were treated also by chitosan as foliar spray application at 100, 200 and $400 \mathrm{ppm}$, as well as, the interaction between them were involved. The obtained results revealed that the higher salinity levels (4000 and $5000 \mathrm{ppm} \mathrm{NaCl})$ caused significant decreases in all vegetative and flowering growth measurements of pot marigold plants compared to control. Maximum reduction was observed at $5000 \mathrm{ppm} \mathrm{NaCl}$ which showed higher increase of the free proline content, sodium and chloride percentages. Meanwhile, the increase in the concentration of salt in the irrigation water resulted in a decrease in the total chlorophylls in leaves and carotene content in flowers. Foliar application of chitosan at concentrations 200 and $400 \mathrm{ppm}$ alleviated the adverse effect of salinity condition thereby vegetative, flowering characters and also chemical constituents were improved. The best level of foliar application of chitosan was at $400 \mathrm{ppm}$. Whereas, non-significant effects were found on the vegetative and floral parameters and some chemical components as a result of the interaction between both aspects studied in comparison with untreated treatment, in most cases, in the two experimental seasons (2018/2019 and 2019/2020).
\end{abstract}

KEYWORDS: Water salinity, Calendula officinalis, Chitosan, Vegetative and flowering growth parameters, Chemical constituents, Foliar-spray application .

\section{Introduction}

Calendula officinalis L. (Marigold) is an annual plant that belongs to the Asteraceae family. It is an important ornamental and medicinal plant. The native region for marigold extends between the regions of the Mediterranean Sea, Egypt and Europe (Nofal et al., 2015). Calendulas plants uses as cut flowers and potted flowering plants (Hamrick, 2003). Marigold play a significant role in human health and has antioxidant functions (Meda et al., 2005).

As one of the abiotic stresses, salinity has become a serious problem affecting the growth and productivity of many plants due to the lack of fresh water supplies, in arid or semi-arid areas, in particular. Salinity in irrigation water and soils induces changes in plant metabolic activities such as hormone modification, photosynthesis and respiration balance, mineral uptake and enzymatic activate inhibition (Mazher et al., 2007). It is a significant factor that decreases the growth and productivity of plants; it affects the total land area of the world and is the main environmental factor limiting the growth and productivity of plants. Ion cytotoxicity and osmotic stress could be responsible for the adverse effects of salinity on plant growth (Hussain et al., 2008). Oxidative stress may also resulted from Imbalances of metabolism triggered by ion toxicity, osmotic stress and deficiency of nutrients under saline conditions (Zhu, 2002).

Chitosan is a natural biopolymer modified from chitin that serves as a potential bio-stimulant and elicitor in agriculture. It is biocompatible, biodegradable and non-toxic, facilitating widespread use theoretically. This enhances physiological 


\section{Abdel-Mola, M.A.M and Ayyat, A.M., 2020}

reaction and decreases the negative effects of abiotic stress by secondary messenger(s) via a stress transduction mechanism. Chitosan treatment enhances the closure of stomata through ABA synthesis and photosynthesis, enhances antioxidant enzymes by nitric oxide and hydrogen peroxide signaling pathways and induces the production of sugars organic acids, amino acids and other metabolites needed for osmotic stress-related adaptation, signaling of stress, and metabolism of energy (Hidangmayum et al., 2019).

This study was designed to investigate the effect of saline water irrigation containing $\mathrm{NaCl}$ and foliar application of chitosan treatments, as well as, their interaction in terms of different vegetative and flowering growth parameters and some chemical constituents of Calendula officinalis L.

\section{Materials and Methods:}

Pot experiments were conducted throughout two successive seasons (2018/2019 and 2019/2020) in a private farm at west of Somosta, Beni-Suef governorate, Egypt.

\subsection{Experimental procedure:}

Local Calendula officinalis seeds L. obtained from the Dept. of Medicinal and Aromatic Plants. Hort. Res. Inst., Agric. Res. Center, Egypt. Seeds were sown in the nursery on the first week of September in both growing seasons. Uniform seedlings 45 days old and nearly $15 \mathrm{~cm}$ in height were transplanted into $30 \mathrm{~cm}$ diameter plastic pot, filled beforehand with $12 \mathrm{~kg}$ of field sandy soil and each contained one seedling. According to Jackson (1973) and Cottenie et al. (1982), as shown in Table (1), physical and chemical properties of soil samples have been determined. Black polyethylene was placed under the pots in order to prevent penetration of roots to the ground. After two weeks from transplanting, in addition to the control plants irrigated with tap water, other plants were irrigated with saline water containing $\mathrm{NaCl}$ at 1000, 2000, 3000,4000 and $5000 \mathrm{ppm}$. In both seasons, irrigation was applied in two day intervals (250 $\mathrm{ml} / \mathrm{pot})$.

Table 1. The physical and chemical properties of the experimental soil.

\begin{tabular}{lccccccc}
\hline O.M. & CaCO3\% & Sand \% & Silt \% & Clay \% & Texture class & pH & ECe (ds/m) \\
\hline 0.8 & 12.40 & 81.70 & 11.80 & 6.50 & sandy loam & 7.8 & 3.2 \\
\hline \multicolumn{7}{c}{ Soluble ions (meq/L) } \\
\hline HCO3- & 2.5 & \multicolumn{7}{c}{ Mg 2+ } & 2.02 & Total N \% 0.049 \\
Cl- & 9.3 & Na+ & 4.55 & Available P 6.40 ppm \\
$\mathrm{Fe}$ & 1.7 & $\mathrm{Zn}$ & 0.32 & Exchange K 1.4 mg/ 1000g (soil) \\
$\mathrm{Ca} 2+$ & 6.9 & $\mathrm{Mn}$ & 0.55 & & \\
\hline
\end{tabular}

Chitosan (2-amino-2-deoxy--d-glucosamine), namely Chito-Care ${ }^{\circledR}$ with a deacetylation degree of $85 \%$, was used as a purified commercial product. To get the desired concentrations of 100, 200 and 400 ppm, chitosan was dissolved in 1 percent acetic acid. Using sodium hydroxide, the $\mathrm{pH}$ of the solution was adjusted to 6.5. The foliage of the plants was sprayed to the point of running off. Plants were sprayed with chitosan concentrations weekly until the beginning of inflorescences harvest.

\subsection{Experimental design:}

The experiment was arranged with 3 replicates in RCBD design in split plot for each treatment (each replicate has 5 plants/treatment). Six water salinity concentrations were used in the main plots (A), while the sub-plots were occupied by four chitosan concentration treatments $(\mathrm{B}) .(\mathrm{A} \times \mathrm{B}) 24$ treatments were the interaction treatments.

\subsection{Experimental treatments:}

\section{Main-plots (A):}

1- Control (tab water).

2- Salinity at $1000 \mathrm{ppm}$ (Sal. 1000ppm).
3- Salinity at $2000 \mathrm{ppm}$ (Sal. 2000ppm).

4- Salinity at $3000 \mathrm{ppm}$ (Sal. 3000ppm).

5- Salinity at $4000 \mathrm{ppm}$ (Sal. 4000ppm).

6- Salinity at $5000 \mathrm{ppm}$ (Sal. 5000ppm).

The sub-plots $(B)$ :

1- Control (spray with tab water).

2- Chitosan at $100 \mathrm{ppm}$ (Ch.1).

3- Chitosan at $200 \mathrm{ppm}$ (Ch.2).

4- Chitosan at $400 \mathrm{ppm}$ (Ch.3).

\subsection{Data recorded:}

\subsubsection{Vegetative growth parameters:}

1- Plant height $(\mathrm{cm})$.

2- Leaf area $\left(\mathrm{cm}^{2}\right)$.

3- Number of main branches/plant.

4- Herb dry weight/plant (g).

\subsubsection{Floral parameters:}

1- Number of inflorescences/plant.

2- Diameter of inflorescences/plant.

3- Inflorescences dry weight (g). 


\subsubsection{Chemical constituents:}

1- Free proline content in dry herb was detected by an acid-ninhydrin method as outlined by Bates et al. (1973).

2- Total chlorophylls $\left(\mathrm{mgg}^{-1}\right)$ were determined in fresh leaves samples according to Welburnand and Lichtenthaler (1984).

3- Carotene content $(\mathrm{mg} / \mathrm{g})$ was determined in fresh flowers samples according to Nagata and Yamashita (1992).

4- Sodium percentage was determined in accordance with the method defined by Cottenie et al. (1982).

5- Chloride percentage was determined according to the method described by Brown and Jackson (1955).

\subsection{Statistical analysis:}

Data collected from the both seasons were tabulated and statistically analyzed in accordance with MSTAT-C (1986) and as defined by Mead et al. (1993), the mean of the observed data was compared using the (L.S.D.) test at the $5 \%$.

\section{RESULTS AND DISCUSSION 3.1. Vegetative parameters}

Data presented in Table (2) concluded that plant height $(\mathrm{cm})$, leaf area $\left(\mathrm{cm}^{2}\right)$, number of main branches/plant and dry weight of herb $(\mathrm{g})$ of marigold plants were significantly decreased due to salinity of irrigation water at 4000 and $5000 \mathrm{ppm}$ in the both seasons tried. While, 1000, 2000 and 3000 ppm had non deleterious effect on vegetative growth parameters as the means of these parameters were closely near to those of control with no significant variation in most cases of the two seasons curried out. The only exception was on leaf area in the two seasons The greatest reduction of vegetative growth parameters was obtained under the highest concentration of $\mathrm{NaCl}(5000 \mathrm{ppm})$ in both seasons. It produced the highest reduction of plant height (36.03 and $34.88 \mathrm{~cm}$ ), leaf area $(22.16$ and 21.69 $\mathrm{cm}^{2}$ ), number of main branches/plant (10.48 and 11.08 ) and herb dry weight/plant (53.65 and $51.45 \mathrm{~g}$ ) compared to untreated plants in the first and second seasons, respectively. The reducing effect of salinity treatments on vegetative growth parameters obtained in this investigation was also pointed out earlier by Ejaz et al. (2015) on calendula plant, Mazhar et al. (2012) on Chrysanthemum indicum and El-Attar (2017) on Antirrhinum majus. The reduction in the growth characteristics of plants as a result of salinity might be attributed to the accumulation of the salts in the soil, which increased the osmotic pressure of tissue cells and decreased the water absorption and/or redistribution of minerals and their utilization (Mazher et al., 2006). Likewise, Pessarakli and
Touchane (2006) illustrated that the salt mechanism can lead to inhibitory of cell division, thereby reducing the rate of plant growth. however, Jou et al. (2006) declared that ATPase is involved in the protein sorting machinery regulated by the endoplasmic reticulum Golgi for both housekeeping function and compartmentalization of excess $\mathrm{Na}^{+}$ under high salinity which could be a limiting factor and serve as an explanation to the obtained result herewith.

Obtained data in Table (2) illustrated that chitosan treatments at 200 and $400 \mathrm{ppm}$ caused considerable and significant augmentation in all vegetative parameters except leaf area only in the two seasons, in comparison with control treatment. The chitosan treatment (400 ppm) caused higher increasing of plant height by $13.46 \%$ and $12.85 \%$, leaf area by $7.47 \%$ and $9.84 \%$, number of main branches/plant by $15.66 \%$ and $20.12 \%$ and herb dry weight/plant by $16.26 \%$ and $16.52 \%$ compared to control in the both experimental seasons, respectively. It might be interesting to mention that no significant differences existed between chitosan at $100 \mathrm{ppm}$ and control. These results are in a harmony with those obtained by Mondal et al. (2013) on Vigna radiate, El-Attar (2017) on Antirrhinum majus, Masjedi et al. (2017) on Triticum aestivum and Ananthaselvi et al. (2019) on Tagetes erecta. Chitosan contains nitrogen in its chemical structure, which is recognized as one of the most important nutrients for plants and soil. When nitrogen is dissolved in chitosan, it gradually penetrates and remains in the soil for longer periods of time and can be effective in this regard. The substantial promotion of chitosan for plant growth may be attributed to an improvement in the main enzyme activities of nitrogen metabolism (glutamine synthetase, nitrate reductase and protease) and increased photosynthesis that enhanced the plant growth (Gornik et al., 2008).

Regarding the interaction between saline water irrigation and foliar chitosan treatments on plant height $(\mathrm{cm})$, leaf area $\left(\mathrm{cm}^{2}\right)$, number of branches/plant and dry weight of herb/plant $(\mathrm{g})$, it was clear that there were insignificant differences on all vegetative growth parameters compared with control plants in both seasons as shown in Table (2). These results mean that chitosan treatments gave positive effect on growth parameters, they reduced the harmful effect of salinity. 
Table 2. Effect of water salinity and chitosan foliar-spray application on plant height $(\mathrm{cm})$, leaf area $\left(\mathrm{cm}^{2}\right)$, number of main branches/plant and herb dry weight/plant (g) of Calendula officinalis L. during 2018/2019 and 2019/2020 seasons.

\begin{tabular}{|c|c|c|c|c|c|c|c|c|c|c|}
\hline \multirow{3}{*}{$\begin{array}{c}\text { Salinity } \\
\text { Treatments } \\
\text { (A) }\end{array}$} & \multicolumn{10}{|c|}{ Chitosan (B) } \\
\hline & $\begin{array}{l}\text { Control } \\
\text { (water) }\end{array}$ & Ch.1 & Ch.2 & Ch.3 & $\begin{array}{c}\text { Mean } \\
\text { (A) }\end{array}$ & $\begin{array}{l}\text { Control } \\
\text { (water) }\end{array}$ & Ch.1 & Ch.2 & Ch.3 & $\begin{array}{l}\text { Mean } \\
\text { (A) }\end{array}$ \\
\hline & \multicolumn{5}{|c|}{ First season $(2018 / 2019)$} & \multicolumn{5}{|c|}{ Second season $(2019 / 2020)$} \\
\hline & \multicolumn{10}{|c|}{ Plant height $(\mathrm{cm})$} \\
\hline Control(water) & 46.8 & 47.2 & 48.5 & 49.8 & 48.08 & 44.8 & 45.4 & 46.8 & 47.2 & 46.05 \\
\hline Sal. 100 & 44.3 & 45.5 & 49.3 & 50.2 & 47.33 & & 43.8 & 46.5 & 46.5 & 44.73 \\
\hline Sal. 21 & 41.5 & 43.7 & 45.2 & 47.6 & 44.50 & & 44.1 & 45.3 & 46.3 & 44.05 \\
\hline Sal. 31 & 39.6 & 41.5 & 44.3 & 47.2 & 43.15 & & 40.6 & 42.1 & 43.6 & 40.88 \\
\hline Sal. 41 & 36.5 & 38.3 & 42.6 & 43.3 & 40.18 & & 36.5 & 40.3 & 42.7 & 38.53 \\
\hline Sal. 5 & 34.3 & 35.7 & 36.5 & 37.6 & 36.03 & 33.3 & 35.3 & 34.8 & 36.1 & 34.88 \\
\hline Mea & 40.5 & 41.98 & 44.4 & 45.95 & & 38.75 & 40.95 & 42.63 & 43.73 & \\
\hline \multirow[t]{2}{*}{ L.S.D. at 5\% } & \multicolumn{2}{|c|}{ A: 5.43} & B: 2.31 & \multicolumn{2}{|c|}{ AB: 5.63} & \multicolumn{2}{|c|}{ A: $\mathbf{5 . 3 5}$} & 2.51 & \multicolumn{2}{|c|}{ AB: 6.12} \\
\hline & \multicolumn{10}{|c|}{ Leaf area $\left(\mathrm{cm}^{2}\right)$} \\
\hline Contro & & 42.05 & 42.32 & 43.28 & 42.30 & 39.12 & 39.65 & 41.08 & 43.15 & 40.75 \\
\hline Sal. 10 & 38.67 & 39.33 & 40.45 & 41.30 & 39.94 & & 37.67 & 38.33 & 39.75 & 38.05 \\
\hline Sal. 200 & 35.41 & 34.27 & 36.18 & 37.85 & 35.93 & & 36.71 & 37.42 & 37.65 & 36.91 \\
\hline Sal. 300 & 34.22 & 33.95 & 35.64 & 37.65 & 35.37 & & 34.15 & 35.77 & 36.79 & 34.96 \\
\hline Sal. 400 & 25.05 & 24.85 & 26.33 & 26.75 & 25.75 & & 24.35 & 25.42 & 27.50 & 25.93 \\
\hline Sal. 500 & 21.88 & 18.67 & 23.42 & 24.65 & 22.16 & 19.75 & 18.95 & 23.42 & 24.65 & 21.69 \\
\hline $\operatorname{Mean}(\mathrm{B})$ & 32.80 & 32.19 & 34.06 & 35.25 & & 31.79 & 31.91 & 33.57 & 34.92 & \\
\hline \multirow[t]{2}{*}{ L.S.D. at 5\% } & \multicolumn{3}{|c|}{ B: 2.31} & \multicolumn{2}{|c|}{ AB: 5.64} & \multicolumn{2}{|l|}{ A: 2.92} & B: 1.83 & \multicolumn{2}{|c|}{ AB: 4.46} \\
\hline & \multicolumn{10}{|c|}{ Number of main branches } \\
\hline Con & & 3.7 & 14.3 & 15.6 & 14.43 & & 14.6 & $\overline{15.2}$ & 14.9 & \\
\hline Sal. 1 & & 14.2 & 13.9 & 14.7 & & & 14.2 & 14 & 14.6 & \\
\hline Sal. 2 & & 12.8 & 13.5 & 14.8 & & & 14.3 & 13.6 & 15.1 & \\
\hline & & 13.7 & 14.4 & 14.5 & 13. & & 13.1 & 12.8 & 14.5 & \\
\hline & 11 & 12.3 & 12.7 & 13.2 & 12. & & 12.3 & 12.1 & 14.3 & \\
\hline & 8. & 10.4 & 10.8 & 12.3 & 10.48 & & 9.2 & 11.4 & 13.3 & 11.08 \\
\hline Mean (B) & 12 & 12.85 & 13.27 & 14.18 & & 12.03 & 12.95 & 13.28 & 14.45 & \\
\hline \multirow[t]{2}{*}{ L.S.D. at $5 \%$} & \multicolumn{2}{|c|}{1.35} & B: 0.88 & \multicolumn{2}{|c|}{ AB: 2.15} & \multicolumn{2}{|c|}{ A: 1.92} & $: 1.18$ & AB: & 2 \\
\hline & & & & & dry & at/nlox & & & & \\
\hline Cont & 67.3 & 70.7 & 73.4 & 74.8 & 71.55 & 65 & 66.3 & 70.4 & 74.8 & 69.25 \\
\hline Sal. 1 & 64.8 & 68.5 & 73.7 & 75.3 & 70.58 & & 67.2 & 69.5 & 72.4 & 68.30 \\
\hline Sal. 2 & 61.2 & 62.7 & 70.4 & 72.6 & 66.73 & 62 & 62.7 & 65.5 & 71.7 & 65.60 \\
\hline pm & 55.3 & 60.3 & 63.2 & 66.2 & 61.25 & & 60.4 & 64.4 & 64.9 & 61.33 \\
\hline Sal. 4 & 53.6 & 54.8 & 58.6 & 61.3 & 57.08 & 52.3 & 54.6 & 57.4 & 63.8 & 57.03 \\
\hline Sal. 5000 ppm & 48.6 & 52.1 & 56.2 & 57.7 & 53.65 & 46.2 & 48.5 & 55.3 & 55.8 & 51.45 \\
\hline & 58.47 & 61.52 & 65.91 & 67.98 & & 57.70 & $\mathbf{5 9 . 9 5}$ & 63.75 & 67.23 & \\
\hline L.S.D. at $5 \%$ & A: 4.96 & & 3.44 & AB: & 8.39 & A: $\mathbf{3 . 8 5}$ & & 2.68 & AB: & 6.54 \\
\hline
\end{tabular}

\subsection{Flowering parameters}

As a flowering ornamental plant, flowers are a significant asset of calendula, so it is not preferred to have reduced flower numbers and quality in containers or landscapes. From the recorded data in Table (3), both treating marigold plants with irrigation water salinity at 4000 and $5000 \mathrm{ppm}$ led to a significant decrease in number of inflorescences, diameter of inflorescences and inflorescences dry weight compared with control plants, in two seasons. The high salt concentration $(5000 \mathrm{ppm})$ produced the highest reduction of number of inflorescences (26.60 and 26.20), diameter of inflorescences (4.49 and $4.36 \mathrm{~cm})$ and inflorescences dry weight $(0.22$ and $0.22 \mathrm{~g}$ ) compared to untreated plants in the both seasons, respectively. Many researchers came to similar conclusions, such as Nofal et al. (2015), Swaefy and El-Ziat (2017) and Adamipour et al. 
Table 3. Effect of water salinity and chitosan foliar-spray application on number of inflorescences, diameter of inflorescences $(\mathrm{cm})$ and inflorescences dry weight $(\mathrm{g})$ of Calendula officinalis $\mathrm{L}$. during 2018/2019 and 2019/2020 seasons.

\begin{tabular}{|c|c|c|c|c|c|c|c|c|c|c|}
\hline \multirow{3}{*}{$\begin{array}{c}\text { Salinity } \\
\text { Treatments } \\
\text { (A) }\end{array}$} & \multicolumn{10}{|c|}{ Chitosan (B) } \\
\hline & $\begin{array}{l}\text { Control } \\
\text { (water) }\end{array}$ & Ch.1 & Ch.2 & Ch.3 & $\begin{array}{l}\text { Mean } \\
\text { (A) }\end{array}$ & $\begin{array}{l}\text { Control } \\
\text { (water) }\end{array}$ & Ch.1 & Ch.2 & Ch.3 & $\begin{array}{l}\text { Mean } \\
\text { (A) }\end{array}$ \\
\hline & \multicolumn{5}{|c|}{ First season(2018/2019) } & \multicolumn{5}{|c|}{ Second season $(2019 / 2020)$} \\
\hline & \multicolumn{10}{|c|}{ Number of inflorescences } \\
\hline Control(water) & 34.0 & 34.4 & 35.4 & 35.6 & 34.85 & 32.4 & 33.2 & 36.0 & 35.6 & 34.30 \\
\hline Sal. 1000 ppm & 30.8 & 33.6 & 34.2 & 35.4 & 33.50 & 28.8 & 29.6 & 33.6 & 34.8 & 31.70 \\
\hline Sal. 2000 ppm & 29.8 & 29.4 & 31.6 & 33.4 & 31.05 & 30.2 & 31.4 & 32.2 & 33.0 & 31.65 \\
\hline Sal. 3000 ppm & 28.8 & 29.4 & 30.8 & 32.8 & 30.45 & 29.8 & 30.2 & 32.8 & 31.6 & 31.10 \\
\hline Sal. 4000 ppm & 26.6 & 27.8 & 28.2 & 29.6 & 28.05 & 27.4 & 27.4 & 29.2 & 29.8 & 27.85 \\
\hline Sal. 5000 ppm & 24.8 & 26.4 & 27.4 & 27.8 & 26.60 & 26.2 & 24.8 & 26.8 & 27.0 & 26.20 \\
\hline Mean (B) & 29.13 & 30.17 & 31.27 & 32.43 & & 29.13 & 29.43 & 31.77 & 31.97 & \\
\hline \multirow[t]{2}{*}{ L.S.D. at $5 \%$} & \multicolumn{2}{|c|}{$A: 4.55$} & B: 1.92 & \multicolumn{2}{|c|}{ AB: 4.68} & \multicolumn{2}{|c|}{ A: 3.68} & B: 1.33 & \multicolumn{2}{|c|}{ AB: 3.23} \\
\hline & \multicolumn{10}{|c|}{ Diameter of inflorescences (cm) } \\
\hline Control(water) & 5.21 & 5.18 & 5.35 & 5.50 & 5.31 & 4.77 & 4.95 & 5.26 & 5.44 & 5.11 \\
\hline Sal. 1000 ppm & 5.11 & 5.32 & 5.38 & 5.46 & 5.32 & 4.82 & 4.72 & 4.90 & 5.15 & 4.90 \\
\hline Sal. 2000 ppm & 5.05 & 5.15 & 5.27 & 5.38 & 5.21 & 4.65 & 4.76 & 4.84 & 5.11 & 4.84 \\
\hline Sal. 3000 ppm & 4.88 & 4.95 & 5.07 & 5.25 & 5.04 & 4.48 & 4.63 & 4.66 & 4.83 & 4.65 \\
\hline Sal. 4000 ppm & 4.50 & 4.75 & 4.88 & 5.05 & 4.80 & 4.22 & 4.47 & 4.50 & 4.67 & 4.47 \\
\hline Sal. 5000 ppm & 4.25 & 4.42 & 4.60 & 4.72 & 4.49 & 4.18 & 4.33 & 4.45 & 4.48 & 4.36 \\
\hline Mean (B) & 4.83 & 4.96 & 5.09 & 5.23 & & 4.52 & 4.64 & 4.77 & 4.95 & \\
\hline \multirow[t]{2}{*}{ L.S.D. at 5\% } & \multicolumn{2}{|l|}{ A: 0.32} & \multirow[t]{2}{*}{ 3: 0.18} & \multicolumn{2}{|c|}{ AB: 0.44} & \multicolumn{2}{|c|}{ A: 0.38} & B: 0.11 & \multicolumn{2}{|c|}{ AB: 0.27} \\
\hline & \multicolumn{9}{|c|}{ Inflorescences dry weight (g) } & \\
\hline Control(water) & 0.26 & 0.27 & 0.27 & 0.29 & 0.27 & 0.28 & 0.29 & 0.29 & 0.33 & 0.30 \\
\hline Sal. 1000 ppm & 0.26 & 0.25 & 0.26 & 0.28 & 0.26 & 0.28 & 0.28 & 0.30 & 0.31 & 0.29 \\
\hline Sal. 2000 ppm & 0.24 & 0.23 & 0.25 & 0.28 & 0.25 & 0.26 & 0.27 & 0.31 & 0.30 & 0.29 \\
\hline Sal. 3000 ppm & 0.25 & 0.22 & 0.27 & 0.27 & 0.25 & 0.25 & 0.27 & 0.29 & 0.29 & 0.28 \\
\hline Sal. 4000 ppm & 0.23 & 0.25 & 0.26 & 0.24 & 0.24 & 0.23 & 0.25 & 0.26 & 0.28 & 0.26 \\
\hline Sal. 5000 ppm & 0.19 & 0.23 & 0.22 & 0.22 & 0.22 & 0.20 & 0.22 & 0.22 & 0.25 & 0.22 \\
\hline Mean (B) & 0.24 & 0.24 & 0.26 & 0.26 & & 0.25 & 0.26 & 0.28 & 0.29 & \\
\hline L.S.D. at $5 \%$ & A: 0.02 & & 0.01 & $\mathbf{A B}$ & 0.02 & A: 0.0 & & B: 0.02 & & 5 \\
\hline
\end{tabular}

(2019) on Calendula officinalis. The reduction in plant growth might be due to the reduction of cell division and cell elongation. This may be attributed to the increase of losing water by leaves so it affects reproduction development (Fricke and Peters, 2002). Also, Greenway and Munns (1980) said that reduction in flowering parameters may ensue from the plants inability to adjust osmotically, counteraction toxicities or related disruptive phenomena or from the excessive energy demand placed upon the metabolic machinery required by such homeostatic systems. Also, Abdalla (2011) demonstrated that The quantity of abscisic acid in the roots is increased by water stress, which is transferred to the shoot from the roots, where it serves as a cytokinin and auxin antagonist, which has very important role in cell enlargement and division, respectively. In addition, it inhibits synthesis of DNA.

Regarding the response of number of inflorescences, diameter of inflorescences and inflorescences dry weight to different concentrations of chitosan. Table (3) proved that all flowering parameters were significantly enhanced due to these abovementioned treatments compared to control treatment in the two experimental seasons. The gradual raise in the concentration of chitosan gave gradual augmentation of flowering characters with the higher values being obtained due to chitosan 400 ppm followed by $200 \mathrm{ppm}$. The increase percentage were $11.33,8.28$ and $8.33 \%$ to number of inflorescences, diameter of inflorescences and inflorescences dry weight in the first season and $9.75,9.51$ and $16.00 \%$ in the second season, respectively, compared to control treatment. Similar findings have been obtained by Wanichpongpan et al. (2001) on gerbera, also, Salachna et al. (2017) on verbena.

The beneficial effects of chitosan may be attributed to its role in various physiological processes; it act as a free radical scavenger or DNAprotective characteristics, and its structure, which 


\section{Abdel-Mola, M.A.M and Ayyat, A.M., 2020}

has large numbers of hydroxyl and amino groups available to react with reactive oxygen species, may be related to the chitosan scavenging mechanism (Salachna and Zawadziñska, 2014). Chitosan also induces endogenous plant hormone synthesis (Uthairatanakij et al., 2007) or induces closure of stomata, which decreases transpiration (Iriti et al., 2009).

Insignificant effects on the flowering aspects were found among the interaction treatments, in most cases, in the two growing seasons. On the whole, foliar application of chitosan alleviated the adverse effect of salinity condition thereby flowering characters were improved.

\subsection{Chemical constituents}

It was noticed from the obtained data in Table (4) that, increasing the salt concentration in water irrigation from 4000 to $5000 \mathrm{ppm}$ showed a significant increase in free proline content compared with control treatment. The plants irrigated with the highest salt concentration $(5000 \mathrm{ppm})$ had the highest mean values of free proline $(4.56$ and $4.82 \mu$ mole $)$ in the two seasons, respectively. Conversely, plants which have been irrigated with tap water had the lowest mean values $(2.12$ and $2.54 \mu$ mole $)$ of free proline content. The increase in the concentration of salt in the irrigation water resulted in a decrease in the total chlorophylls and carotene content in flowers which reached its lowest values of (total chlorophylls 1.35 and $1.41 \mathrm{mg} / \mathrm{g}$ ) and (carotene content 0.720 and $0.808 \mathrm{mg} / \mathrm{g}$ ) in the first and second seasons, respectively compared with control plants which gave the highest value. All salt concentrations in the irrigation water treatments caused significant augmentation in the leaves contents of sodium and chloride. The only exception was the treatment of water salinity at $1000 \mathrm{ppm}$ for chloride content in the second season. The increase was parallel to the increase of salinity levels. Therefore, the application of high level of salinity (5000 ppm) gave the highest values of sodium and chloride contents in leaves which reached 2.21 and $2.02 \%$ for sodium and 1.71 and $1.76 \%$ for chloride in both experimental seasons, respectively. Such findings are in line with those obtained by many researches who reported increments in free proline content like, Kozminska et al. (2017) on calendula, El-Attar (2017) on snapdragon and Krupa-Malkiewicz and Smolik (2019) on petunia, results of $\mathrm{Na}$ and $\mathrm{Cl} \%$ was found also by Don et al. (2010) on Gerbera jamesonii, Mahmoud (2016) on Calendula officinalis, Koksal et al. (2016) on Tagetes erecta and El-Attar (2017) on Antirrhinum majus due to raising salinity. Decreasing total chlorophylls detected in this investigation was also recorded by Lacramioara et al. (2014), (Swaefy and El-Ziat, 2017) and Kozminska et al. (2017) on
Calendula officinalis. However, some other authors pointed out that chlorophyll and carotenoid contents in C. officinalis were not affected by salinity (Mirlotfi et al., 2015). This apparent contradiction may be attributed to the use of different experimental growth conditions in these reports.

The rise in proline content is one of calendula plant defensive mechanisms against salinity stress. Greenway and Munns (1980) found that proline can be considered as a stabilizer of osmotic pressure within a cell and can make a contribution to cytoplasmic osmotic adjustment . Azevedo Neto and Silva (2015) suggested that increased activity of enzymes, complexes and membranes of proteins, protein stabilisation, cell redox homeostasis maintenance, the stocks of carbon and nitrogen, regulating cytosolic $\mathrm{pH}$ and removing free radicals are the functions attributed to proline accumulation. Inhibition of chlorophyll synthesis, along with activation of its degradation by the enzyme chlorophyllase, caused the reduction of chlorophyll levels in salt-treated plants (Santos, 2004). This is not the only explanation for photosynthesis inhibition in the presence of salt, because $\mathrm{NaCl}$ also inhibits main enzymes such as Rubisco and PEP carboxylase that are involved in this process (Soussi et al., 1998).

With respect to the response of the contents of free proline to different concentration of chitosan, data obtained in Table (4) indicated that the content of free proline, was significantly decreased due to chitosan at 200 and $400 \mathrm{ppm}$ in the second season except at $400 \mathrm{ppm}$ in the first season compared to check control treatments. The lowest contents of free proline were achieved due to the following treatments in descending order: chitosan foliar application at $400 \mathrm{ppm}$ followed by $200 \mathrm{ppm}$ over those of check treatment by 17.45 and $10.65 \%$ in the first season, and by 22.65 and $13.49 \%$ in the second season, respectively. Whereas, no significant differences were recorded between the aforementioned two treatments. These findings align with those published by El-Attar (2017) on Antirrhinum majus plants.

With regard to the influence of chitosan concentrations, data given in Table (4) proved that these treatments had a favorable impact on enhancing the accumulation of total chlorophylls and carotene content. The increase of the total chlorophylls and carotene contents in flowers was gradual due to the gradual raise in the examined concentration. The highest contents of total chlorophylls were obtained from the following chitosan concentrations in descending order: chitosan at $400 \mathrm{ppm}$ followed by $200 \mathrm{ppm}$ then $100 \mathrm{ppm}$. These three treatments increased the total chlorophylls over those of control plants by $29.71,20.29$ and $12.32 \%$ in the first season and by $19.86,11.64$ and $0.68 \%$ in the second one, respectively. While, for carotene content in flowers, 
Table 4. Effect of water salinity and chitosan foliar-spray application on free proline, total chlorophylls, carotene content/flowers, sodium and chloride percentages of Calendula officinalis L. during 2018/2019 and 2019/2020 seasons.

\begin{tabular}{|c|c|c|c|c|c|c|c|c|c|c|}
\hline \multirow{2}{*}{$\begin{array}{c}\text { Salinity } \\
\text { Treatments } \\
\text { (A) }\end{array}$} & $\begin{array}{c}\text { Control } \\
\text { (water) }\end{array}$ & Ch.1 & Ch.2 & Ch.3 & $\begin{array}{l}\text { Mean } \\
\text { (A) }\end{array}$ & $\begin{array}{c}\text { Control } \\
\text { (water) }\end{array}$ & Ch.1 & Ch.2 & Ch.3 & $\begin{array}{c}\text { Mean } \\
(\mathrm{A})\end{array}$ \\
\hline & \multicolumn{5}{|c|}{ First season(2018/2019) } & \multicolumn{5}{|c|}{ Second season $(2019 / 2020)$} \\
\hline & \multicolumn{10}{|c|}{ Free proline ( $\mu$ mole g-1 dry weight) } \\
\hline Control (water) & 2.25 & 2.23 & 2.11 & 1.88 & 2.12 & 3.05 & 2.75 & 2.40 & 1.95 & 2.54 \\
\hline Sal. 1000 ppm & 2.63 & 2.45 & 2.34 & 2.41 & 2.46 & 2.82 & 3.10 & 2.60 & 2.45 & 2.74 \\
\hline Sal. 2000 ppm & 2.55 & 2.67 & 2.48 & 2.25 & 2.49 & 3.38 & 3.25 & 2.78 & 2.66 & 3.02 \\
\hline Sal. 3000 ppm & 3.42 & 3.25 & 3.05 & 3.15 & 3.22 & 4.62 & 3.92 & 3.75 & 2.88 & 3.79 \\
\hline Sal. 4000 ppm & 4.35 & 3.85 & 3.40 & 3.30 & 3.72 & 4.77 & 4.34 & 3.97 & 3.75 & 4.21 \\
\hline Sal. 5000 ppm & 5.10 & 4.68 & 4.72 & 3.75 & 4.56 & 4.95 & 4.84 & 4.92 & 4.55 & 4.82 \\
\hline Mean (B) & 3.38 & 3.19 & 3.02 & 2.79 & & 3.93 & 3.70 & 3.40 & 3.04 & \\
\hline \multirow{2}{*}{ L.S.D. at 5\% } & \multirow{2}{*}{\multicolumn{3}{|c|}{ B: 0.55}} & \multicolumn{2}{|c|}{ AB: 1.34} & \multicolumn{2}{|l|}{$\mathrm{A}: 1.48$} & B: 0.43 & \multicolumn{2}{|l|}{ AB: 1.05} \\
\hline & & & & \multicolumn{5}{|c|}{ Total chlorophylls (mg/g leaf F.W) } & & \\
\hline Control (water) & 1.62 & 1.68 & 1.85 & 2.02 & 1.79 & 1.55 & 1.58 & 1.83 & 1.94 & 1.73 \\
\hline Sal. 1000 ppm & 1.55 & 1.73 & 1.83 & 1.96 & 1.77 & 1.61 & 1.52 & 1.75 & 1.91 & 1.70 \\
\hline Sal. 2000 ppm & 1.38 & 1.60 & 1.66 & 1.88 & 1.63 & 1.48 & 1.47 & 1.72 & 1.86 & 1.63 \\
\hline Sal. 3000 ppm & 1.33 & 1.52 & 1.61 & 1.76 & 1.56 & 1.42 & 1.50 & 1.58 & 1.67 & 1.54 \\
\hline Sal. 4000 ppm & 1.28 & 1.44 & 1.57 & 1.63 & 1.48 & 1.37 & 1.41 & 1.45 & 1.62 & 1.46 \\
\hline Sal. 5000 ppm & 1.14 & 1.32 & 1.46 & 1.46 & 1.35 & 1.32 & 1.36 & 1.43 & 1.51 & 1.41 \\
\hline Mean (B) & 1.38 & 1.55 & 1.66 & 1.79 & & 1.46 & 1.47 & 1.63 & 1.75 & \\
\hline \multirow[t]{2}{*}{ L.S.D. at 5\% } & A: 0.28 & \multicolumn{2}{|c|}{ B: 0.09} & \multicolumn{2}{|c|}{ AB: 0.22} & A: 0.15 & \multicolumn{2}{|c|}{ B: 0.07} & \multicolumn{2}{|l|}{ AB: 0.17} \\
\hline & \multicolumn{10}{|c|}{ Carotene content / flowers (mg/g F.W.) } \\
\hline Control (water) & 0.925 & 0.948 & 1.065 & 1.208 & $\mathbf{1 . 0 3 7}$ & 1.045 & 1.118 & 1.220 & 1.285 & $\mathbf{1 . 1 6 7}$ \\
\hline Sal. 1000 ppm & 0.904 & 0.885 & 0.955 & 1.190 & 0.984 & 1.003 & 0.988 & 1.085 & 1.145 & 1.055 \\
\hline Sal. 2000 ppm & 0.835 & 0.795 & 0.915 & 1.084 & 0.907 & 0.932 & 0.97 & 1.102 & 1.110 & 1.029 \\
\hline Sal. 3000 ppm & 0.752 & 0.770 & 0.874 & 0.966 & 0.841 & 0.875 & 0.92 & 0.964 & 0.976 & 0.934 \\
\hline Sal. 4000 ppm & 0.711 & 0.733 & 0.810 & 0.882 & 0.784 & 0.740 & 0.86 & 0.923 & 0.963 & 0.873 \\
\hline Sal. 5000 ppm & 0.645 & 0.668 & 0.722 & 0.845 & 0.720 & 0.694 & 0.75 & 0.875 & 0.905 & 0.808 \\
\hline Mean (B) & 0.795 & 0.799 & 0.890 & 1.029 & & 0.882 & 0.93 & 1.028 & 1.064 & \\
\hline \multirow[t]{2}{*}{ L.S.D. at 5\% } & A: 0.225 & \multicolumn{2}{|c|}{ B: 0.078} & \multicolumn{2}{|c|}{ AB: 0.190} & A: 0.2 & & B: 0.045 & AB: 0.1 & \\
\hline & & & & & & m\% & & & & \\
\hline Control (water) & 0.86 & 0.79 & 0.75 & 0.72 & 0.78 & 0.93 & 0.91 & 0.84 & 0.79 & 0.87 \\
\hline Sal. 1000 ppm & 1.32 & 1.27 & 1.17 & 1.22 & 1.25 & 1.37 & 1.31 & 1.25 & 1.17 & 1.28 \\
\hline Sal. 2000 ppm & 1.55 & 1.49 & 1.42 & 1.35 & 1.45 & 1.48 & 1.51 & 1.39 & 1.33 & 1.43 \\
\hline Sal. 3000 ppm & 1.72 & 1.58 & 1.45 & 1.38 & 1.53 & 1.64 & 1.62 & 1.57 & 1.53 & 1.59 \\
\hline Sal. 4000 ppm & 1.95 & 1.88 & 1.79 & 1.73 & 1.84 & 1.82 & 1.77 & 1.84 & 1.65 & 1.77 \\
\hline Sal. 5000 ppm & 2.31 & 2.24 & 2.12 & 2.18 & 2.21 & 2.15 & 2.07 & 1.98 & 1.89 & 2.02 \\
\hline Mean (B) & 1.62 & 1.54 & 1.45 & 1.43 & & 1.56 & 1.53 & 1.48 & 1.39 & \\
\hline L.S.D. at 5\% & A: 0.33 & & S 0.21 & AB: 0 & & A: 0.27 & & 3: N.S 0.19 & AB: 0. & \\
\hline & & & & & & ride \% & & & & \\
\hline Control (water) & 1.18 & 1.12 & 1.17 & 0.95 & 1.11 & 1.22 & 1.14 & 1.15 & 1.08 & 1.15 \\
\hline Sal. 1000 ppm & 1.38 & 1.32 & 1.28 & 1.21 & 1.30 & 1.29 & 1.24 & 1.23 & 1.19 & 1.24 \\
\hline Sal. 2000 ppm & 1.52 & 1.47 & 1.45 & 1.40 & 1.46 & 1.48 & 1.42 & 1.39 & 1.34 & 1.41 \\
\hline Sal. 3000 ppm & 1.62 & 1.58 & 1.55 & 1.49 & 1.56 & 1.60 & 1.63 & 1.54 & 1.47 & 1.56 \\
\hline Sal. 4000 ppm & 1.69 & 1.72 & 1.63 & 1.61 & 1.66 & 1.71 & 1.68 & 1.58 & 1.55 & 1.63 \\
\hline Sal. 5000 ppm & 1.75 & 1.72 & 1.70 & 1.65 & 1.71 & 1.83 & 1.79 & 1.71 & 1.69 & 1.76 \\
\hline Mean (B) & 1.52 & 1.49 & 1.46 & 1.39 & & 1.52 & 1.48 & 1.43 & 1.39 & \\
\hline L.S.D. at $5 \%$ & A: 0.14 & B: & S 0.16 & AB: 0 & & A: 0.11 & & B: N.S 0.18 & $\mathbf{A F}$ & 0.44 \\
\hline
\end{tabular}

the increment due to these treatments over check improved leaf chlorophyll content in sour orange treatment was $29.43,11.95$ and $0.50 \%$ in the first seedling at different concentrations, since chitosan season and 20.63, 16.55 and $6.23 \%$ in the second probably play a vital role in raising the number of one, consecutively. Such findings are consistent by chloroplasts/cell, the size and number of cells/unit Mohamed et al. (2018), they found that the area, and in stimulating chlorophyll synthesis. The application of foliar chitosan was significantly effects of chitosan, in increasing chlorophylls were 
confirmed in cucumber, cowpea and radish (Farouk et al., 2011). These results are in harmony with Khan et al. (2002) who illustrated that application of chitosan enhanced photosynthesis in leaves of soybean and maize. By enhancing endogenous levels of cytokinins, which promote chlorophyll synthesis, chitosan can relieve the effect of water stress on photosynthetic pigments. As for the effect of chitosan treatments on $\mathrm{Na}$ and $\mathrm{Cl}$ percentages in the leaves of calendula plants, obtained data postulated that there was no significance between control check treatment and all chitosan treatments.

With regards to the interaction between salt stress and chitosan concentrations on proline, sodium and chloride contents, data showed that the highest mean values of proline, sodium, and chloride contents were obtained in plants irrigated with saline water $5000 \mathrm{ppm}$ and receiving no chitosan treatment (5.10, $4.95 \mu$ mole for proline, $2.31,2.15 \%$ for sodium and $1.75,1.83 \%$ for chloride) in the two seasons, respectively. Conversely, the lowest values of proline , sodium and chloride (1.88 and $1.95 \mu$ mole for proline, 0.72 and $0.79 \%$ for sodium and 0.95 and $1.08 \%$ for chloride) in the two experimental seasons, respectively, were obtained from plants irrigated with tap water and sprayed with chitosan at $400 \mathrm{ppm}$. Whereas, on the total chlorophylls and carotene contents inside flowers, results indicated that the highest values $(2.02$ and $1.94 \mathrm{mg} / \mathrm{g}$ for total chlorophylls) and (1.208 and $1.285 \mathrm{mg} / \mathrm{g}$ for carotene contents) in the first season and in the second one, respectively were found from plants irrigated with tap water and sprayed with chitosan at $400 \mathrm{ppm}$. While, the lowest values of total chlorophylls and carotene contents (1.14 and $1.32 \mathrm{mg} / \mathrm{g}$ for total chlorophylls) and $(0.645$ and $0.694 \mathrm{mg} / \mathrm{g}$ for carotene contents) in the first season and in the second one, respectively, were obtained from plants irrigated with saline water at $5000 \mathrm{ppm}$ without spraying chitosan.

Finally in this study, it could be concluded that to reduce the effect of salinity stress, supplying Calendula officinalis L. plants with the high concentration of chitosan foliar spray at $400 \mathrm{ppm}$, to obtain the best vegetative growth, flowering yield and chemical constituents of pot marigold plants which were irrigated with saline water under Beni-Suef governorate conditions.

\section{REFERENCES}

Abdalla MM (2011). Beneficial effects of diatomite on growth, biochemical contents and polymorphic DNA in Lupinus albus grown under water stress. Agri. Biol. J. North Am. 2: 207-220.

Adamipour N, Khosh-Khui M, Salehi H, Rho H (2019). Effect of vermicompost on morphological and physiological performances of pot marigold
(Calendula officinalis L.) under salinity conditions. Adv. Hort. Sci., 33(3): 345-358.

Ananthaselvi K, Thamarai Selvi SB, Subramanian S, Chandrasekhar CN (2019). Effect of chitosan on growth and yield of African marigold (Tagetes erecta L.) under drought induced stress condition. International Journal of Chemical Studies. 7(3): 3612-3615.

Azevedo Neto AD, Silva EC (2015). Physiology and biochemistry of salt stress tolerance in plants. In: Chakraborty U, Chakraborty B (ed.). Abiotic stresses in crop plants. Wallingford: CABI, pp: 278.

Bates LS, Waldem RP, Teare ID (1973). Rapid determination of free proline for water stress studies. Plant and Soil, 39, 205 - 207.

Brown JG, Jackson PK (1955). A note on the potentiometric determination of chloride. Proc. Amer. Soc. Hort. Sci., 65:187-194.

Cottenie A, Verloo M, Kiekens L, Velghe G, Camerlynck R (1982). Chemical analysis of plant and soil. Laboratory of Analytical and Agro chemistry, State Univ. Ghent. Belgium. pp: 100-129

Don KKG, Xia YP, Zhu Z, Le C, Wijeratne AW (2010). Some deleterious effects of long-term salt stress on growth, nutrition and physiology of gerbera (Gerbera jamesonii L.) and potential indicators of its salt tolerance. J. Plant Nutr., 33(13): 2010-2027.

Ejaz M, Parveen S, Shah R, Ali M, Kakar H (2015). Effect of saline irrigation water on growth parameters of calendula (Calendula officinalis) seeds. Life Sci. Int. J., 9(4): 3287-3300.

El-Attar AB (2017). Is the performance of snapdragon plants (Antirrhinum majus L.) influenced by some bio-stimulators under salinity stress?. Journal of horticultural science \& ornamental plants. 9 (2): 52-64.

Farouk S, Mosa AA, Taha AA, Ibrahim HM, ElGahmery AM (2011). Protective effect of humic acid and chitosan on radish (Raphanus sativus L. var. sativus) plants subjected to cadmium stress. J. Stress Physiol. Biochem. 7(2): 99-116.

Fricke W, Peters WS (2002). The biophysics of leaf growth in salt-stressed barley. A study at the cell level. Plant Physiol., 129:374-88.

Gornik K, Grzesik M, Romanowska-Duda B (2008). The effect of chitosan on rooting of grapevine cuttings and on subsequent plant growth under drought and temperature stress. J. Fruit Ornam Plant Res. 16: 333-343.

Greenway HR, Munns R (1980). Mechanisms of salt tolerance in non-halophytes. Ann. Rev. Plant Physiol.,31,149 -190.

Hamrick D (2003). Calendula. In: Hamrick, D. (ed) Ball Redbook crop production, vol 2. 17 edn. Ball Publishing, Batavia, IL, 277-278 p.

Hidangmayum A, Dwivedi B, Katiyar D, Hemantaranjan A (2019). Application of chitosan 
on plant responses with special reference to abiotic stress. Physiol Mol Biol Plants. 25(2): 313-326.

Hussain TM, Hazara M, Sultan Z, Saleh BK, Gopal GR (2008). Recent advances in salt stress biology a review. Biotechnology and Molecular Biology Reviews, 3(1), pp.8-13.

Iriti M, Picchi V, Rossoni M, Gomarasca S, Ludwig N, Gargano M. and Faoro F. (2009). Chitosan antitranspirant activity is due to abscisic acid- dependent stomatal closure. Environ. Exp. Bot., 66: 493-500.

Jackson ML (1973). "Soil Chemical Analysis". Englewood Cliffs, New Prentice. Hall INC., New York.

Jou Y, Chiang C, Jauh G, Yen HC (2006). Functional characterization of ice plant SDKI, an AAA-type ATPase associated with the endoplasmic reticulum-Golgi network, and its role in adaptation to salt stress. Plant Physiol., 141(1):135-146.

Khan MH, Singha KLB, Panda SK (2002). Changes in antioxidant levels in Oryza sativa L. roots subjected to $\mathrm{NaCl}$ salinity stress. Acta Physiologia Plantarum. 24: 145-148.

Koksal N, Alkan-Torun A, Kulahlioglu I, Ertargin E, Karalar E (2016). Ion uptake of marigold under saline growth conditions. Springer Plus, 5(139): 1-12.

Kozminska A, Al Hassan M, Kumar D, Oprica L, Martinelli F, Grigore MN, Vicente $O$ and Boscaiu $M$ (2017). Characterizing the effects of salt stress in Calendula officinalis L. J Appl Bot Food Qual., 90(10):323-329.

Krupa-Malkiewicz M, Smolik B (2019). Alleviative effects of chitosan and ascorbic acid on Petunia $\times$ atkinsiana D. Don under salinity. Eur. J. Hortic. Sci. 84(6): 359-365.

Lacramioara O, Grigore NM, Vochit G. (2014). Impact of saline stress on growth and biochemical indices of Calendula officinalis seedlings. Omanian Biotechnological Letters, 20(6): 11007-11017.

Mahmoud EA (2016). Enhancement the characters of calendula plant grown under saline and non-saline conditions by using growth stimulants. Ph.D. Thesis, Fac. Agric., Cairo Univ. Egypt, pp: 96-123.

Masjedi MH, Roozbehani A, Baghi M (2017). Assessment effect of chitosan foliar application on total chlorophyll and seed yield of wheat (Triticum aestivum L.) under water stress conditions. Journal of crop nutrition science. 3(4): 14-26.

Mazher AAM, Eid RA, Abd EIAziz NGA (2006). Effect of Microbien under salt stress on modulation, growth and chemical constituents of Sesbania egyptiaca in sandy soil. Bull NRC, Egypt, 31(3):247-268.

Mazher AMA, El-Quesni EMF, Farahat MM (2007). Responses of ornamental and woody trees to salinity. Wold J. Agric. Sci., 3(3): 386-395.
Mazhar AAM, Shedeed SI, Abd El-Aziz NG, Mahgoub MH (2012). Growth, flowering and chemical constituents of Chrysanthemum indicum L. plant in response to different levels of humic acid and salinity. J. Appl. Sci. Res., 8(7): 3697-3706.

Mead R, Currow RN, Harted AM (1993). Statistical methods in agricultural and experimented biology. $2^{\text {nd }}$ Ed. Chapman and Hall, Landon pp. 1044

Meda A, Lamien CH, Romito M, Millogo J, Nacoulma GO (2005). Determination of the total phenolic, flavonoid and prolin contents in Burkina fasan honey. As well as their radical scavenging activity. Food Chem. 91: 571-577.

Mirlotfi A, Bakhtiari S, Bazrgar AB (2015). Effect of seed priming on germination and seedling traits of Marigold (Calendula officinalis) at saline condition. Biol. Forum Int. J. 7, 1626-1630.

Mohamed SA, Ahmed HS, El-Baowab AA (2018). Effect of chitosan, putrescine and irrigation levels on the drought tolerance of sour orange seedlings. Egypt. J. Hort. Vol. 45, No. 2, pp. 257-273.

Mondal MM, Malek MA, Puteh AB, Ismail MR (2013). Foliar application of chitosan on growth and yield attributes of mungbean (Vigna radiata $\mathrm{L}$. Wilczek). Bangladesh J. Bot. 42(1): 179-183.

MSTAT-C (1986). A microcomputer program for the design management and analysis of agronomic research experiments (version 4.0), Michigan State Univ., U.S.A.

Nagata M, Yamashita I (1992). Simple method for simultaneous determination of chlorophyll and carotenoids in tomato fruit. J. Japan. Soc. Food Sci. Technol., 39 (10), 925-928.

Nofal FH, El-Segai MU, Seleem EA (2015). Response of Calendula officinalis L. plants to growth stimulants under salinity stress. AmericanEurasian J. Agric. \& Environ. Sci., 15 (9): 17671778.

Pessarakli M, Touchane H (2006). Growth responses of Bermuda grass and seashore paspalum under various levels of sodium chloride stress. J. Food, Agric. and Environ., 4(3/4):240-243.

Salachna P, Byczyńska A, Jeziorska I, Udyez E (2017). Plant growth of Verbena bonariensis L. after chitosan, gellan gum or iota-carrageenan foliar applications. World Scientific News. 62: 111-123.

Salachna P, Zawadziñska A (2014). Effect of chitosan on plant growth, flowering and corms yield of potted freesia. J. Ecol. Eng., 15(3): 97-102.

Santos CV (2004). Regulation of chlorophyll biosynthesis and degradation by salt stress in sunflower leaves. Sci. Hort. 103, 93-99.

Soussi M, Ocaña A, Lluch C (1998). Effect of salt stress on growth, photosynthesis and nitrogen fixation in chick-pea (Cicer arietinum L.) cultivars. J. Exp. Bot. 49, 1339-1347. 


\section{Abdel-Mola, M.A.M and Ayyat, A.M., 2020}

Swaefy HM, El-Ziat RA (2017). Response of double-flowered Marigold to salinity and biostimulant applications. Middle East Journal of Agriculture. 06 (04): 1519-1525.

Uthairatanakij A, Teixeira Da Silva JA, Obsuwan K. (2007). Chitosan for improving orchid production and quality. Orchid Sci. Biotechnol., 1(1): 1-5.

Wanichpongpan P, Suriyachan K, Chandrkrachang S (2001). Effect of chitosan on the growth of gerbera flower plant (Gerbera jamesonii). Chitin and chitosan: chitin and chitosan in life science, Yamaguchi, Japan, pp 198-201.

Welburn AR, Lichtenthaler H (1984). Formula and program to determine total carotenoids and chlorophyll $\mathrm{a}$ and $\mathrm{b}$ of leaf extracts in different solvents. "Advances in Photosynthesis Research" (Sybesma C. Ed.) Vol. П, pp. 9-12.

Zhu JK (2002). Salt and drought stress signal transduction in plants. Annual review of plant biology, 53, p.247.

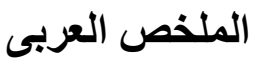

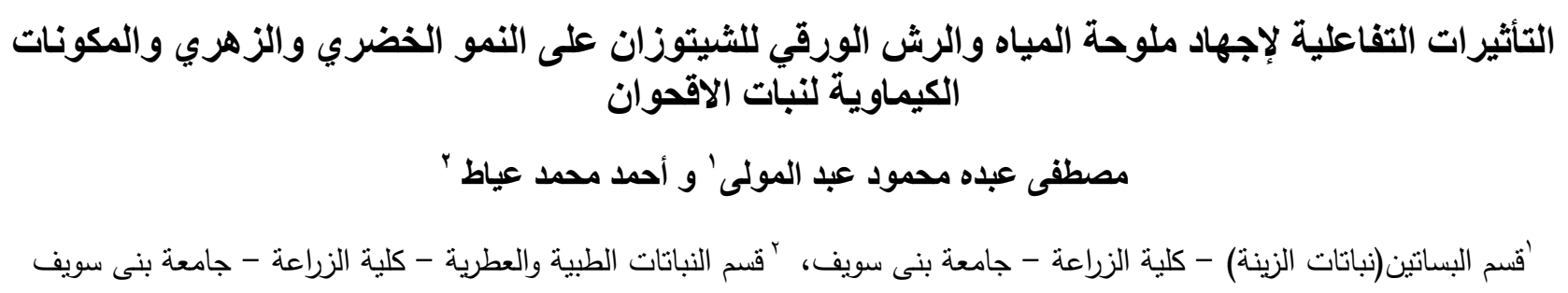

